\title{
BUDIDAYA ITIK PEDAGING DI DESA ANGGASWANGI KECAMATAN GODONG KABUPATEN GROBOGAN
}

\author{
Arso Setyaji1 ${ }^{1}$ Ellya Rakhmawati², M Yusuf Setia Wardana ${ }^{3}$ \\ 1 Pendidikan Bahasa Inggris, Universitas PGRI Semarang \\ 2 PGPAUD, Universitas PGRI Semarang \\ ${ }^{3} P G S D$, Universitas PGRI Semarang
}

\begin{abstract}
Abstrak
Desa Anggaswangi merupakan salah satu wilayah Republik Indonesia yang terletak di Desa Godong, Kecamatan Grobogan, Provinsi Jawa Tengah. Ada beberapa warga yang mencoba berbudidaya itik pedaging tapi gagal. Ada dua vokasi yang disiapkan untuk mengatasi ekonomi di desa Anggaswangi, yaitu: (a). Vokasi berdasarkan budidaya itik pedaging, dan (b). Vokasi berdasarkan industri rumahan, berupa olahan itik pedaging. Fokus program kegiatan ini adalah untuk meningkatkan pendapatan anggota keluarga Mitra melalui program unggulan itik pedaging. Pembentukan kelompok dalam program kegiatan ini, meliputi: (1). Produksi dan pengembangan klaster usahatani itik pedaging, dan (2). Hasil klaster pemasaran. Dari 1875 ekor itik pedaging yang dikelola oleh 15 peternak, jumlah keuntungan keseluruhan adalah $\mathrm{Rp}$ 17.608.854,00 dengan rata-rata keuntungan 15 mitra sebesar Rp 1.173.923,60. Keuntungan bebek terbesar mitra KKN-PPM di Desa Anggaswangi adalah Bapak Suwarno dengan keuntungan $\mathrm{Rp} 1.407 .875,00$. Sedangkan yang paling sedikit keuntungannya adalah Rp 945.241,00 dari mitra KKN PPM Ibu Rustinah.
\end{abstract}

Kata-kata Kunci:

bebek, budidaya,

anggaswangi

\section{Pendahuluan}

Desa Anggaswangi terletak di daerah kabupaten Grobogan, tepatnya di kecamatan Godong. Secara geografis desa Anggaswangi terletak di sebelah utara desa Kemploko, sebelah timur desa Guci, sebelah selatan desa Truko dan sebelah barat persawahan. Desa Anggaswangi berjarak kurang lebih 3-5 $\mathrm{km}$ dari kecamatan Godong. Jika ditempuh dengan sepeda motor membutuhkan waktu kurang lebih 5-10 menit dengan kecepatan sedang.

Desa Anggaswangi terdiri atas empat dusun yaitu dusun Grengseng, Manggian, Kerep dan Anggaswangi. secara administrasi desa Anggaswangi terdiri atas 2 RW setiap RW terdiri atas 8 RT. RW 1 terdiri atas RT 1, RT 2, RT 3 dan RT 4 yang terletak di dusun Anggaswangi, RW 2 RT 1 terletak di dusun Manggian, RW 2 RT 2 terletak di dusun Grengseng, RW 2 RT 3 dan RT 4 terletak di dusun Kerep. Dusun Grengseng terletak di sebelah barat balai desa.

Desa Anggaswangi memiliki beberapa potensi, yaitu potensi di bidang pendidikan, kewirausahaan, pertanian, peternakan dan kesehatan. Dalam bidang pendidikan desa Anggaswangi memiliki potensi seperti adanya madrasah diniyah, SD Negeri Anggaswangi, TK PGRI, PAUD An-Nafi'. Selain itu di desa Anggaswangi juga dekat dengan SDN 03 dan SDN 05 Godong. Di bidang kewirausahaan, Anggaswangi memiliki potensi yang sangat besar karena dekat dengan pasar Truko dan pasar Godong. Kondisi sekarang ini sangat bagus jika didirikan warung makanan dengan menu kreasi bebek karena banyak sekali masyarakat Anggaswangi yang memiliki penghasilan dengan berternak bebek, baik bebek petelur maupun bebek pedaging. Selain itu juga terdapat pabrik pembuat sandal hotel yang mampu menyerap banyak tenaga kerja dari desa Anggaswangi dan produk tersebut sudah didistribusikan ke luar kota. Banyak juga usaha-usaha rumahan seperti pembuat tas, dompet dan hiasan dari rajutan, produksi ceriping pisang, pecel puli, kerupuk puli yang dijadikan sebagai kuliner unggulan desa Anggaswangi. Pada bidang pertanian Anggaswangi memiliki lahan pertanian yang sangat luas, hal tersebut menjadikan faktor utama masyarakat Anggaswangi bermatapencaharian sebagai petani. Lahan persawahan Anggaswangi biasanya ditanami padi, jagung, kacang-kacangan dan polowijo lainnya. Wilayah Anggaswangi juga cocok digunakan untuk berternak, terbukti dengan banyaknya masyarakat yang berternak yaitu berternak domba, ayam, mentok, bebek dan telur burung puyuh. Di bidang kesehatan desa Anggaswangi dipercayai

\footnotetext{
* Corresponding author.

E-mail Addresses: setyajiarso@yahoo.co.id (Arso Setyaji), rakhmawati.ellya@gmail.com (Ellya Rakhmawati) ayuest@gmail.com (M Yusuf Setia Wardana)
} 
oleh kecamatan Godong sebagai kampung KB dengan didukung program posyandu balita dan posyandu lansia yang berjalan setiap bulan.

Mata pencarian penduduk Desa Anggaswangi Kecamatan Godong sebagian besar sebagai petani, buruh tani dan home industri. Para pekerja di bidang pertanian tidak menuntut pendidikan yang tinggi. Buruh tani banyak waktu luang karena pekerjaan yang tersedia bersifat musiman sehingga di luar musimnya penduduk Desa Anggaswangi menjadi pengangguran. Beberapa orang berkelompok mencoba memelihara itik. Usaha yang dirintis warga ini tidak dapat berjalan dengaan baik, bahkan tergolong rugi. Hal ini disebabkan karena biaya yang diperlukan untuk budidaya itik pedaging sangat besar. Ketidakberhasilan budidaya itik pedaging tersebut diakibatkan ada beberapa hal, terutama: (a). Kebersihan kandang yang tidak dapat dilaksanakan secara rutin, (b). Pengetahuan tentang budidaya itik pedaging sangat terbatas, (c). Mahalnya pakan ternak itik pedaging, biaya tenaga kerja dan obat-obatan, (d). Faktor lingkungan sepertiiklim, gizi, peternakan, dan kesehatan (Anonimous, 2013; Maylinda, dkk., 1991; Park, 2004). Menurut Kateran (2002), pakan berperan sangat penting dalam usaha peternakan itik pedaging. Bahan pakan yang digunakan untuk kebutuhan pakan itik di lokasi penelitian diperoleh petani dengan cara membeli. Biaya produksi ternak itik berasal dari biaya pakan lebih besar dari $70 \%$ (Kateran, 2002).

\section{Metode}

Metode yang digunakan untuk mengatasi permasalahan adalah dengan melakukan pendekatan strategis program yang dilakukan dalam beberapa tahap, sebagai berikut:

a) Identifikasi masalah

Identifikasi masalah yang dilakukan di Desa Anggaswangi, Kecamatan Godong bertujuan untuk mengetahui kondisi kehidupan masyarakat mitra, mencatat permasalahan yang ada dalam memberdayakan industri rumah tangga, dan mendata potensi yang ada di Desa Anggaswangi, Kecamatan Godong, Kabupaten Grobogan. Kegiatan ini akan diperoleh data mengenai: 1) Keluarga masyarakat mitra tentang (a). Pekerjaan, (b). Penghasilan per-hari, (c). Kualitas hidup, (d). Tingkat pendidikan, (e). Profil rumah, (f). Jumlah tanggungan keluarga, (g). Potensi diri masing anggota keluarga mitra, 2) Potensi desa tentang (1) mata pencarian penduduk, (2) APBDes, (3) kepemimpinan dan manajemen pemerintahan, (4) jumlah UKM, (5) ketersediaan bahan baku budidaya itik pedaging, (6) lembaga keuangan desa, (7) fasilitas desa, 3) Budaya masyarakat tentang (1) adat istiadat, (2) kebiasaan masyarakat, (3) budaya kerja mayarakat, (4) aktivitas sosial budaya masyarakat, 4) Permasalahan yang perlu mendapat penanganan tentang (1) ekonomi penduduk, (2) lingkungan, (3) produktivitas, (4) sosial budaya

Dari hasil identifikasi ini dapat ditentukan solusi yang paling tepat untuk mengatasi permasalahan yang terjadi di Desa Anggaswangi, Kecamatan Godong, Kabupaten Grobogan.

b) Sosialisasi Program

kegiatan yang dilakukan dalam sosialisasi program ini adalah 1) Melakukan sosialisasi terhadap keluarga mitra Program Terpadu Pemberdayaan Masyarakat Berspektif Gender dan masyarakat Desa Anggaswangi tentang budidaya itik pedaging yang mempunyai nilai ekonomis untuk meningkatkan pendapatan anggota keluarga mitra, 2) Melakukan sosialisasi tentang program pemberdayaan ini kepada masyarakat, tokoh masyarakat, PKK, Kelompok Dasa Wisma supaya dapat bekerjasama untuk mensukseskan program KKN-PPM, 3) Menghubungi dinas/instansi terkait di Kabupaten Grobogan, dalam hal ini (1) Badan Pemberdayaan Masyarakat Desa, (2) Dinas Perindustrian, (3) Dinas Pertanian dan Peternakan, (4) Badan Perencanaan dan Pembangunan Daerah supaya bersama-sama dengan LPPM Universitas PGRI Semarang untuk membina anggota keluarga Mitra sehingga pendapatannya bertambah. b) Program Penyuluhan dan Pelatihan

Tujuan Umum Program Penyuluhan dan Pelatihan adalah 1) Memberikan penyuluhan tentang beberapa cara peningkatan pendapatan, 2) Meningkatkan keterampilan mitra binaan dan elemen masyarakat, 3) Memberikan penyuluhan tentang pengembangan produk dan pengembangan pemasaran produk, 4) Demonstrasi Plotting / Pelatihan, 5) Monitoring dan Evaluasi Program.

\section{Hasil dan Pembahasan}

Beberapa program yang sudah dilaksanakan pada program ini adalah

1) Sosialisasi dan penyuluhan tentang pemilihan bahan baku, tenik pengolahan dan budidaya itik pedaging.

Kegiatan yang dilakukan TIM KKN PPM tdalam kegiatan ini diantaranya adalah, melakukan koordinasi dengan Badan Pemberdayaan Masyarakat Desa, Rapat koordinasi dengan Kepala Desa. Perangkat Desa. Rapat koordinasi dengan pelaku UKM dan ketua kelompok keluarga mitra binaan, 
Mempersiapkan materi sosialisasi, kebutuhan teknis yang menunjang sosialisasi dan penyuluhan, Menyusun acara dan agenda sosialisasi dan penyuluhan,

2) Pelatihan budidaya itik pedagingkepada keluarga mitra binaan

Dalam kegiatan ini tim KKN sebelumnya sudah Rapat koordinasi dengan Kepala Desa, perangkat desa, pelaku UKM dan keluargamitra binaan, selanjutnya pelatihan kegiatan budidaya itik pedaging dilakukan sebelum penerjunan mahasiswa KKN PPM. Lima belas (15) calon peternak yang bermitra dengan TIM KKN PPM hadir dalam pelatihan ini. Pelatihan ini berisi tentang pelatihan budidaya itik pedaging dari pemilihan bibit, pembuatan kandang, memanajemen pengeluaran, pembuatan pakan yang bisa menekan biyaya produksi tetapi tidak mengurangi hasil produksi maupun masa panen, mengenal penyakit itik pedaging dan solusinya, dan pemasaran.

3) Monitoring dan pendampingan proses budidaya itik pedaging.

Monitoring dan pendampingan budidaya itik pedaging dilakukan secara berkala oleh mahasiswa, kegiatan tersebut diantaranya adalah Menjalin koordinasi dengan Kepala Desa, perangkat desa, pelaku UKM, dan fasilitator, Survei secara berkala terhadap proses produksi ke Anggota Warga Kelompok Mitra Binaan, Pencatatan hasil monitoring secara berkala, Diskusi membahas hasil monitoring secara berkalatentang kasus-kasus yang dijumpai dalam monitoring

4) Evaluasi Budidaya Itik pedaging

Evaluasi budidaya itik pedaging ini bertujuan untuk mengetahui hasil yang dicapai para mitra selama kegiatan KKN PPM berlangsung. Dalam evaluasi ini para peternak menyampaikan komposisi pakan yang mereka pakai hingga mencapai panen. Peternak yang mendapatkan hasil berat itik pedaging terbaik bisa membagikan pengalamannya kepada peternak sehingga menghasilkan berat ideal tetapi tidak mengeluarkan pengeluaran yang banyak, sehingga menghasilkan keuntungan yang maksimal.

5) Sosialisasi penyuluhan tentang pengetahuan pemasaran itik pedaging.

Kegiatan penyuluhan pemasaran sebelumnya sudah dijadikan satu paket pada saat pelatihan budidaya itik pedaging. peternak itik pedaging dapat menjual itik pedaging ke pengepul baik dari daerah Grobogan sendiri maupun daerah luar Grobogan, misal: Semarang, Pati dan Demak. Sistem penjualannya, petani di beri pilihan untuk menjual itik pedaging dengan sistem kiloan untuk bebek berusia 45 hari atau dengan sistem ekoran untuk bebek berusia lebih dari 60 hari. Untuk itik pedaging berusia 45 hari petani bisa menjual itik pedaging kiloan dengan harga Rp. 23.000 per kg.

6) Bekerjasama dengan tengkulak dari dalam daerah maupun luar daerah

Pada dasarnya di daerah grobogan sendiri sudah ada tengkulak yang siap untuk membeli itik pedaging di daerah Anggaswangi. Namun TIM KKN PPM juga bekerja sama dengan tengkulak yang berasal dari luar daerah semisal Semarang dan Demak supaya lebih memudahkan warga dalam mencari pasar yang lebih luas.

7) Pelatihan Pembukuan dan Manajemen

Pelatihan pembukuan dan manajemen ini bertujuan untuk melatih peternak supaya dapat mengetahui pengeluaran sekaligus pendapatan yang akan didapat peternak pada saat masa panen. Peternak juga didampingi oleh mahasiswa dalam melaksanakan kegiatan pembukuan dam manajemen pakan ini.

8) Mendirikan warung bebek goreng dan catering olahan masakan bebek.

Selain teknik budidaya itik pedaging, warga juga dibekali oleh tim KKN-PPM untuk mengolah itik pedaging menjadi olahan makanan yang pastinya dapat bernilai jual lebih tinggi. Macam-macam olahan yang dilatihkan adalah abon itik pedaging, itik pedaging bakar dan itik pedaging geprek. Warga juga di dampingi membuka warung itik pedaging bakar dan juga catering masakan olahan itik pedaging. Dengan adanya warga yang membuka warung dan catering olahan itik pedaging, semakin memudahkan peternak untuk memasarkan hasil budidaya itik pedaging. Selain itu, juga dapat meningkatkan penghasilan warga dalam bentuk masakan olahan itik pedaging.

9) Evaluasi Pemasaran

Evaluasi pemasaran ini dilaksanakan bersamaan dengan evaluasi budidaya itik pedaging. Tujuan evaluasi pemasara ini untuk mengetahui berapa keuntungan yang didapat setelah di jual oleh para tengkulak. Kemampuan peternak dalam memanajemen pakan atau menentukan pakan alternatif dalam budidaya ini pasti mempengaruhi nilai keuntungan yang didapat oleh peternak. Peternak yang memiliki bebek dengan berat tertinggi belum tentu mendapatkan keuntungan yang tertinggi juga jika manajemen pakan/ olahan pakan yang di pakai memakai pakan yang mahal.

Program budidaya itik pedaging ini diperuntukkan untuk seluruh warga masyarakat. Rencana awal program ini hanya untuk 10 angota budidaya itik, dikarenakan atusias warga Anggaswangi yang berkeinginan mencoba berbudidaya itik pedaging, TIM KKN PPM UPGRIS menambah jumlah peternak yang bermitra dengan program KKN PPM menjadi 15 Anggota Kelompok. Setiap peternak mendapatkan 
125 ekor itik pedaging, pakan awal ternak (50 kg Pur, 50 kg Katul), Kebutuhan pemuatan kandang, 2 Paket obat-obatan dan tempat minum bebek. Masyarakat juga diberikan sosialisasi dan penyuluhan tentang budidaya itik pedaging, pelatihan tekhnik budidaya itik pedaging dan tentang pemasaran budidaya itik pedaging.

Dalam manajemen pakan itik, peternak memberikan makanan pur pabrik untuk itik yang berusia 1 - 14 hari. Pada usia itik lebih dari 14 hari, peternak memberikan makanan campuran dengan kolaborasi ampas tahu, bekatul, pur, dan juga sayur-sayuran yang sudah layu seperti kangkung, bayam dll. Makanan campuran tersebut dapat diperoleh di desa anggaswangi dengan sangat mudah. Dengan makanan campuran tersebut, dapat menekan biaya konsumsi pakan sehingga meningkatkan penghasilan bersih warga dari budidaya itik pedaging ini.

Dalam obat-obatan, warga cukup mencampurkan minuman bebek dengan vitamin. Selain itu, bebek yang sudah berusia 10 hari dilakukan vaksinasi agar terbebas dari penyakit. Dalam pelaksanaan budidaya itik pedaging, warga didampingi oleh mahasiswa KKN-PPM. Setiap harinya, mahasiswa KKN-PPM mendampingi warga untuk memantau perkembangan itik pedaging, administrasi manajemen pengeluaran warga dalam berbudidaya itik pedaging, vaksinasi, perawatan kandang, sampai ke pemasaran baik dalam bentuk olahan makanan maupun dijual ke tengkulak. Dengan manajemen keuangan yang baik dan benar warga akan dapat mengetahui berapa keuntungan berbudidaya itik pedaging.

Tabel 1. Keuntungan mitra budidaya itik pedaging

\begin{tabular}{|c|c|c|}
\hline No & $\begin{array}{c}\text { Nama } \\
\text { Peternak }\end{array}$ & Keuntungan \\
\hline 1 & $\begin{array}{l}\text { Peternak } \\
\text { Suwarno }\end{array}$ & Rp $1.407 .875,00$ \\
\hline 2 & Slamet & Rp $1.393 .404,00$ \\
\hline 3 & Riyanto & $\operatorname{Rp} 1.346 .156,00$ \\
\hline 4 & Surati & $\operatorname{Rp} 1.286 .514,00$ \\
\hline 5 & Budi & Rp 1.261.520,00 \\
\hline 6 & Murian & $\operatorname{Rp} 1.230 .286,00$ \\
\hline 7 & Darman & Rp 1.178.657,00 \\
\hline 8 & Suprojo & $\operatorname{Rp} 1.176 .856,00$ \\
\hline 9 & Sutrisno & Rp 1.175.681,00 \\
\hline 10 & Nurhadi & Rp 1.172.233,00 \\
\hline 11 & Rifai & Rp 1.073.432,00 \\
\hline 12 & Kusen & Rp 1.022.280,00 \\
\hline 13 & Ngatimin & Rp $987.326,00$ \\
\hline 14 & Priyono & $\mathrm{Rp} \quad 951.420,00$ \\
\hline 15 & Rustinah & $\mathrm{Rp} \quad 945.214,00$ \\
\hline \multicolumn{2}{|c|}{ Jumlah } & $\operatorname{Rp} 17.608 .854,00$ \\
\hline
\end{tabular}

Berdasarkan tabel keuntungan itik pada saat panen, total keuntungan dari 15 mitra KKN-PPM adalah Rp 17.608.854,00 dengan rata-rata keuntungan dari 15 mitra tersebut adalah Rp 1.173.923,60. Keuntungan itik terbesar dari mitra KKN-PPM di Desa Anggaswangi adalah Bapak Suwarno dengan keuntungan Rp 1.407.875,00. Sedangkan keuntungan paling sedikit adalah Rp 945.241,00 dari mitra KKN PPM Ibu Rustinah.

Bagian pemasaran, peternak itik pedaging dapat menjual itik pedaging ke pengepul baik dari daerah Grobogan sendiri maupun daerah luar Grobogan, semisal: Semarang, Pati dan Demak. Sistem penjualannya, petani di beri pilihan untuk menjual itik pedaging dengan sistem kiloan untuk bebek berusia 45 hari atau dengan sistem ekoran untuk bebek berusia lebih dari 60 hari. Untuk itik pedaging berusia 45 hari petani bisa menjual itik pedaging kiloan dengan harga Rp. 23.000-23.000 per kg. Rata-rata berat itik pedaging pada usia 45 hari adalah 1 - 1,3 kg.

Melihat hasil atau keuntungan yang dicapai para mitra KKN-PPM di Desa Anggaswangi ini, para mitra KKN-PPM sudah berani melanjutkan budidaya itik pedaging dengan jumlah bibit yang lebih besar 
lagi (250 - 500 ekor) , bahkan yang semula hanya ada 15 peternak dari mitra KKN-PPM bertambah 17 peternak yang ikut berbudidaya itik pedaging. Sehingga jumlah budidaya itik pedaging di desa Anggaswangi menjadi 32 peternak. Bahkan mahasiswa KKn-PPM yang semula hanya mendampingi peternak juga tertarik menjadi peternak bebek. Tercatat ada 5 mahasiswa KKN-PPM UPGRIS yang menjadi peternak itik pedaging dan berani menurunkan jumlah bibit 250 -1000 ekor

\section{Simpulan dan Saran}

Budidaya itik pedaging di desa anggaswangi terbukti dapat meningkatkan penghasilan warga desa angaswangi. keuntungan dari 15 mitra KKN-PPM adalah Rp 17.608.854,00 dengan rata-rata keuntungan dari 15 mitra tersebut adalah Rp 1.173.923,60. Keuntungan itik terbesar dari mitra KKN-PPM di Desa Anggaswangi adalah Bapak Suwarno dengan keuntungan Rp 1.407.875,00. Sedangkan keuntungan paling sedikit adalah Rp 945.241,00 dari mitra KKN PPM Ibu Rustinah.

Melihat hasil atau keuntungan yang dicapai para mitra KKN-PPM di Desa Anggaswangi ini, para mitra KKN-PPM sudah berani melanjutkan budidaya itik pedaging dengan jumlah bibit yang lebih besar lagi, bahkan yang semula hanya ada 15 peternak dari mitra KKN-PPM bertambah 17 peternak. Sehingga jumlah budidaya itik pedaging di desa Anggaswangi menjadi 32 peternak. Bahkan mahasiswa KKN-PPM yang semula hanya mendampingi peternak juga tertarik menjadi peternak bebek. Tercatat ada 5 mahasiswa KKN-PPM UPGRIS yang menjadi peternak itik pedaging dan berani menurunkan jumlah bibit 250 -1000 ekor.

Berdasarkan simpulan diatas adapun saran yang dapat penulis sampaikan yaitu melihat keuntungan yang didapat, petani sudah saatnya lebih berani melanjutkan usahanya lebih besarlagi. Selain itu kerjasama pemasaran ke daerah lain harus lebih di tingkatkan lagi.

Ucapan terimakasih kami sampaikan kepada Kemenristekdikti, Universitas PGRI Semarang, Desa Anggaswangi serta mahasiswa KKN-PPM yang telah membantu serta mensukseskan kegiatan KKN-PPM ini. Semoga hasil kegiatan KKN PPM ini dapat bermanfaat bagi masyarakat indonesia

\section{Daftar Pustaka}

Anonimous. 2013. Qualitative traits and Quantitaive traits in animals. http://web2.mendelu.cz/af_291_projekty2/vseo/stranka.php?kod=471. Diakses 2 Desember 2014.

Bappeda Provinsi Jawa Tengah, publikasi Jawa Tengah Dalam Angka 2014, diakses tanggal 24 Maret 2015 jam 15.30 WIB

Badan Pusat Statistik Kabupaten Grobogan, publikasi Kabupaten Grobogan Dalam Angka 2014 danKecamatan Dalam Angka 2014, diakses tanggal 23 Maret 2015, jam 14.01 WIB

Ekowati, T., E. Prasetyo dan H.Oxtovianto. 2005. Manajemen Permodalan Pada Anggota KTTI "Maju Jaya” Untuk Pengembangan Usaha ternak Itik di Kecamatan Brebes Kabupaten Brebes. Seminar Nasional Tehnologi Peternakan dan Veteriner.

Kateran, P.P. 2002. Kebutuhan Gizi Itik Petelur dan Itik Pedaging. Wartazoa Vol 12 No 2 Tahun 2002. p: $37-46$

Maylinda, S., G. Ciptadi., dan S. Wahyuningsih. 1991. Pengantar Genetika.

Malang: Fakultas Peternakan Universitas Brawijaya Malang.

Park, H-B. 2004. Genetic Analysis of Quantitative Traits Using Domestic Animals. A Candidate Gene and Genome Scanning Approach. Acta. Universitatis Upsaliensis. Comprehensive Summaries of Uppsala Dissertations From Faculty of Medicine: 51-60.

Rupabumi Wilayah Administrasi Desa-Kelurahan Kabupaten Grobogan Tahun 2012; http://grobogan.go.id/pemerintahan/desa/desa-desa-di-kec-godong/177-desa-anggaswangi-kecgodong, diunduh pada 6 February 2013

Sudargo, dkk. 2015. Laporan Kegiatan Hibah KKN-PPM Dikti: Budidaya Itik Pedaging Sebagai Upaya Peningkatan Penghasilan Tambahan Warga Binaan Pemberdayaan Masyarakat Desa Gempolsari 
Kecamatan Gabus Kabupaten Pati Jawa Tengah. Semarang: Universitas PGRI Semarang (tidak dipublikasikan).

Surya, Gunawan, 2009. Beternak Itik Pedaging. Jakarta: Petra.

https://id.wikipedia.org/wiki/Anggaswangi,_Godong,_Grobogan; diunduh pada 2 Februari 2016, pukul 15.55 . 